Laughing Out Loud 
Also by Andrew Horton

Three More Screenplays by Preston Sturges (editor)

Play It Again, Sam: Retakes on Remakes (coeditor with Stuart McDougal)

Buster Keaton's "Sherlock Jr." (editor)

The Films of Theo Angelopoulos: A Cinema of Contemplation

The Last Modernist: The Films of Angelopoulos (editor)

Bones in the Sea: Time Apart on a Greek Island

Writing the Character-Centered Screenplay

Russian Critics on a Cinema of Glasnost

(coeditor with Michael Brashinsky)

Inside Soviet Film Satire: Laughter with a Lash (editor)

The Zero Hour: Glasnost and Soviet Cinema in Transition (coeditor with Michael Brashinsky)

Comedy/Cinema/Theory (editor)

The Films of George Roy Hill

Modern European Filmmakers and the Art of Adaptation

(coeditor with Joan Magretta) 


\section{Laughing Out}

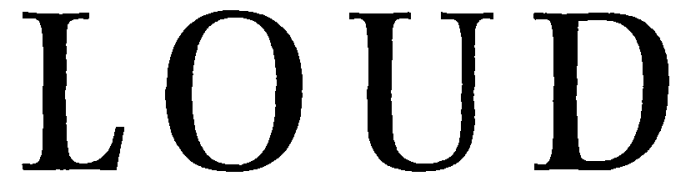

\section{Writing the Comedy-Centered Screenplay}

\section{ANDREW HORTON}




\section{University of California Press \\ Berkeley and Los Angeles, California}

University of California Press, Ltd.

London, England

2000 by the Regents of the University of California

\section{Library of Congress Cataloging-in-Publication Data}

\section{Horton, Andrew.}

Laughing out loud: writing the comedy-centered screenplay / Andrew Horton.

$$
\text { p. } \quad \mathrm{cm} \text {. }
$$

Includes bibliographical references and index.

ISBN 978-0-520-22015-7 (pbk. : alk. paper)

1. Motion picture authorship. 2. Comedy films. I. Title.

$$
\text { PN1996.H668 } 2000
$$

99-17669

$808.2^{\prime} 3-\mathrm{dc} 21$

CIP

Manufactured in the United States of America

151413

$\begin{array}{llllll}12 & 11 & 10 & 9 & 8 & 7\end{array}$

The paper used in this publication meets the minimum requirements of ANSI/NISO Z39.48-1992 (R 1997) (Permanence of Paper). @ 
For Caroline,

my very funny and loving daughter 

To the memory of those who made us laugh. The motley mountebanks, the clowns, the buffoons, in all times and in all nations, whose efforts have lightened our burden a little...

Preston Sturges, Sullivan's Travels 
